\title{
Harmonisasi Metode Hybrid Dalam Penentuan Pupuk Bersubsidi di Wilayah Jawa Timur
}

Harmonization Of Hybrid Methods In Subsidized Fertilizer In East Java Region

\author{
Ilham \\ Program Studi Sistem Informasi, Jurusan Teknologi, Fakultas Saintek, \\ Universitas Islam Negeri Sunan Ampel Surabaya \\ Jl. Ahmad Yani 117, Surabaya 61121, Jatim \\ Email: ilham@uinsby.ac.id
}

\begin{abstract}
Abstrak - Penelitian ini dilakukan untuk mengetahui seberapa besar kebutuhan pupuk yang ada di tiap kabupaten sekitar wilayah jawa timur. Sistem pendukung keputusan bertujuan mengukur serta mengevaluasi penjualan yang masih kurang dari $100 \%$ dari alokasi target penjualan. Untuk menindak lanjuti hasil evaluasi terhadap suatu kabupaten diterapkan dua metode hybrid, yaitu Analytic Hierarchy Proses dan Technique for Order Preference by Similarity to Ideal Solution untuk melakukan perangkingan terhadap penjualan pupuk bersubsidi. Dengan adanya harmonisasi metode hybrid ini dapat ditentukan kriteria beragam dan memecahkan masalah pengambilan keputusan yang menggunakan presepsi manusia dengan membandingkan bobot kepentingan sebagai input utamanya. Sistem pendukung keputusan menggunakan metode AHP dan TOPSIS mampu menganalisa dan menyimpulkan variabel perbandingan rencana, realisasi dan potensi penjualan di masing-masing kabupaten, hasil penelitian dari sampling propinsi Jawa Timur penjualan terendah adalah Lumajang dengan nilai 0,4993 karena penjualan masih kurang dari $100 \%$ yaitu 300 ton dari total rencana 1216 ton, dengan mengetahui penjualan yang kurang dari $100 \%$ di masing-masing kabupaten.
\end{abstract}

Kata Kunci: Sistem Pendukung Keputusan, AHP, dan Topsis

Abstract - This research was conducted to find out how much fertilizer needs exist in each district around the East Java region. Decision support system aims to measure and evaluate sales that are still less than $100 \%$ of the allocation of sales targets. To follow up the results of an evaluation of a district applied two hybrid methods, namely Analytic Hierarchy Process and Technique for Order Preference by Similarity to Ideal Solution to rank the sale of subsidized fertilizer. With the harmonization of hybrid methods, various criteria can be determined and the problem of decisionmaking that uses human perception can be determined by comparing the weight of interest as the main input. Decision support system using AHP and TOPSIS method is able to analyze and conclude the comparison variable plan, realization and sales potential in each district, the results of research from the sampling of East Java province the lowest sales are Lumajang with a value of 0.4993 because sales are still less than $100 \%$ namely 300 tons of the total plan of 1216 tons, knowing sales were less than $100 \%$ in each district.

Keyword : Decision Support System, AHP and Topsis

\section{PENDAHULUAN}

Dalam dunia industri proses penyediaan dan perhitungan penjualan masih menggunakan metode sederhana atau masih menggunakan perhitungan konvensional dan masih mendapatkan beberapa kendala dalam pengolahan data. Sehingga proses tersebut mengalami beberapa permasalahan seperti, informasi data yang sangat lama diterima petugas lapangan ketika ada rapat mendadak dengan anggota Dewan Perwakilan Rakyat atau Badan Pengawas Keuangan, tidak akuratnya data yang disalurkan oleh Distributor dan data yang sudah dilaporkan perusahaan kepada Auditor Lapangan serta buruknya dalam mengukur penjualan di masing-masing Kabupaten.

Sistem Pendukung Keputusan diharapkan dapat menentukan nilai-nilai negative di masing-masing kabupaten, dengan mengetahui nilai negative tersebut, diharapkan petugas lapangan akan mensosialisasikan pupuk bersubsidi terhadap penjualan yang masing dibawah ketentuan.

Sehingga diperlukan adanya aplikasi sistem pendukung keputusan perangkingan penjualan per kabupaten pupuk bersubsidi dengan metode Analytic Hierarchy Process (AHP) dan TOPSIS.

\section{TINJAUAN PUSTAKA}

2.1 Sistem Pendukung Keputusan

Sistem pendukung keputusan sebagai sistem yang digunakan untuk mendukung dan membantu pihak manajemen melakukan pengambilan keputusan pada kondisi semi terstruktur dan tidak terstruktur. Pada dasarnya konsep DSS hanyalah sebatas pada kegiatan membantu para manajer melakukan penilaian serta menggantikan posisi dan peran manajer.

Secara Umum, Sistem Pendukung Keputusan adalah sebuah sistem yang mampu memberikan kemampuan, baik kemampuan pemecahan masalah maupun kemampuan pengkomunikasian untuk masalah semi terstruktur. Secara khusus (Kadarsah Suryadi, 1998), Sistem Pendukung Keputusan adalah sebuah sistem yang mendukung kerja seorang manager maupun sekelompok manager dalam memecahkan masalah semi-terstruktur dengan cara memberikan informasi ataupun usulan menuju pada keputusan tertentu (Sprague, 1982). 


\subsection{Analytical Hierarchy Process}

Proses pengambilan keputusan pada dasarnya adalah memilih suatu alternative. Peralatan utama Analytical Hierarchy Process (AHP) adalah sebuah hirarki fungsional dan input utamanya persepsi manusia. Dengan hirarki, suatu masalah komplek dan tidak terstruktur dipecahkan kedalam kelompok-kelompoknya. Kemudian kelompok-kelompok tersebut diatur menjadi suatu bentuk hirarki (Saaty ,1993).

Dalam penjabaran hirarki tujuan, tidak ada pedoman yang pasti seberapa jauh pengambilan keputusan menjabarkan tujuan menjadi tujuan yang lebih rendah. Pengambilan keputusanlah yang menentukan saat penjabaran tujuan ini berhenti, dengan memperhatikan keuntungan atau kekurangan yang diperoleh bila tujuan tersebut diperinci lebih lanjut.

Langkah perhitungan AHP :

\begin{tabular}{c|cccc} 
& $\mathrm{A}_{1}$ & $\mathrm{~A}_{2}$ & $\ldots$ & $\mathrm{A}_{\mathrm{n}}$ \\
\hline $\mathrm{A}_{1}$ & $\mathrm{a}_{11}$ & $\mathrm{a}_{12}$ & $\cdots$ & $\mathrm{a}_{1 \mathrm{n}}$ \\
$\mathrm{A}_{2}$ & $\mathrm{a}_{21}$ & $\mathrm{a}_{22}$ & $\ldots$ & $\mathrm{a}_{2 \mathrm{n}}$ \\
$\cdot$ & $\cdot$ & $\cdot$ & $\cdot$ & $\cdot$ \\
$\cdot$ & $\cdot$ & $\cdot$ & $\cdot$ & $\cdot$ \\
$\cdot$ & $\cdot$ & $\cdot$ & $\cdot$ & $\cdot$ \\
$\mathrm{A}_{\mathrm{n}}$ & $\mathrm{a}_{\mathrm{n} 1}$ & $\mathrm{a}_{2 \mathrm{n}}$ & $\ldots$ & $\mathrm{a}_{\mathrm{nn}}$
\end{tabular}

Gambar 2.1 Matriks Perbandingan Berpasangan

Matrik An x n merupakan matriks resiprokal. Dan diasumsikan terdapat $n$ elemen, yaitu $\mathrm{w}_{1}, \mathrm{w}_{2} \ldots \mathrm{w}_{\mathrm{n}}$ yang akan dinilai secara perbandingan. Nilai (judgment) perbandingan secara berpasangan antara $\left(\mathrm{w}_{1}, \mathrm{w}_{2}\right)$ dapat dipresentasikan seperti matriks tersebut.

$$
\frac{w_{i}}{w_{j}}=a_{(i, j)} ; i . j=1,2 \ldots n
$$

Dalam hal ini matriks perbandingan adalah matrik A dengan unsure-unsurnya adalah $\mathrm{a}_{\mathrm{ij}}$, dengan $\mathrm{i}, \mathrm{j}=1,2 \ldots \mathrm{n}$.

\begin{tabular}{c|cccc} 
& $\mathrm{A}_{1}$ & $\mathrm{~A}_{2}$ & $\cdots$ & $\mathrm{A}_{\mathrm{n}}$ \\
\hline $\mathrm{A}_{1}$ & $\mathrm{~W}_{1} / \mathrm{W}_{1}$ & $\mathrm{~W}_{1} / \mathrm{W}_{2}$ & $\cdots$ & $\mathrm{W}_{1} / \mathrm{W}_{\mathrm{n}}$ \\
$\mathrm{A}_{2}$ & $\mathrm{~W}_{2} / \mathrm{W}_{1}$ & $\mathrm{~W}_{2} / \mathrm{W}_{2}$ & $\ldots$ & $\mathrm{W}_{2} / \mathrm{W}_{\mathrm{n}}$ \\
$\cdot$ & $\cdot$ & $\cdot$ & $\cdot$ & $\cdot$ \\
$\cdot$ & $\cdot$ & $\cdot$ & $\cdot$ & $\cdot$ \\
$\cdot$ & $\cdot$ & $\cdot$ & $\cdot$ & $\cdot$ \\
$\mathrm{A}_{\mathrm{n}}$ & $\mathrm{W}_{\mathrm{n}} / \mathrm{W}_{1}$ & $\mathrm{~W}_{\mathrm{n}} / \mathrm{W}_{2}$ & $\ldots$ & $\mathrm{W}_{\mathrm{n}} / \mathrm{W}_{\mathrm{n}}$
\end{tabular}

Gambar 2.2 Matriks Perbandingan Preferensi
Nilai-nilai $\mathrm{W}_{\mathrm{i}} / \mathrm{W}_{\mathrm{j}}$, dengan $\mathrm{i}, \mathrm{j}=1,2 \ldots \mathrm{n}$, didapat dari partisipan, yaitu orang-orang yang berkompeten dalam permasalahan yang dinamis.

Bila matriks ini dikalikan dengan vektor kolom $\mathrm{W}=$ $\left(\mathrm{w}_{1}, \mathrm{w}_{2} \ldots \mathrm{w}_{\mathrm{n}}\right)$, maka diperoleh hubungan :

$\mathrm{AW}=\mathrm{nW}$

Bila matrik A diketahui dan ingin diperoleh nilai $\mathrm{W}$, maka dapat diselesaikan melalui persamaan berikut:

$[\mathrm{A}-\mathrm{nI}] \mathrm{W}=0$

Dimana I matriks adalah identitas.

Persamaan (2) ini dapat menghasilkan solusi yang tidak nol bila (jika dan hanya jika) $n$ merupakan eigenvalue dari A dan $\mathrm{W}$ adalah eigenvektor-nya.

Setelah eigenvalue matriks perbandingan A tersebut diperoleh, misalnya $\lambda_{1}, \lambda_{2} \ldots \lambda_{n}$, dan berdasarkan matriks $A$ yang mempunyai keunikan, yaitu $a_{i j}=1$ dengan $i=1,2 \ldots n$, maka

$$
\sum_{\mathrm{i}=1}^{\mathrm{n}} \quad \lambda_{\mathrm{I}}=\mathrm{n}
$$

Disini semua eigenvalue bernilai nol, kecuali satu yang tidak nol, yaitu eigenvalue maksimum. Kemudian jika penilaian yang dilakukan konsiten, akan diperoleh eigen value maksimum dari A yang bernilai $n$.

Untuk mendapatkan $\mathrm{W}$, maka dapat dilakukan dengan mensubstitusikan harga eigen value maksimum pada persamaan.

$$
\mathrm{AW}=\lambda_{\text {maks }} \mathrm{W}
$$

Selanjutnya Persamaan (2) dapat diubah menjadi :

$\left[\mathrm{A}-\lambda_{\text {maks }} \mathrm{I}\right] \mathrm{W}=0$

Untuk memperoleh harga nol, maka yang perlu diset adalah :

$\mathrm{A}-\lambda_{\text {maks }} \mathrm{I}=0$

Berdasarkan persamaan (4) dapat diperoleh harga $\lambda_{\text {maks }}$

Dengan memasukkan harga $\lambda_{\text {maks }}$ ke persamaan (3) dan ditambah dengan persamaan

$$
\sum_{i=1}^{n} w_{i}^{2}=1
$$

maka akan diperoleh bobot masing-masing elemen operasi $\left(\mathrm{W}_{\mathrm{i}}\right.$, dengan $\left.\mathrm{i}=1,2 \ldots \mathrm{n}\right)$ yang merupakan eigenvektor yang bersesuaian dengan eigenvalue maksimum.

Matriks bobot yang diperoleh dari hasil perbandingan secara berpasangan tersebut, harus mempunyai hubungan kardinal dan original, sebagai berikut.

Hubungan Kardinal $: a_{i j} \cdot a_{j k}=a_{i k}$

Hubungan Ordinal : $A_{i}>A_{j}, A_{j}>A_{k}$ maka $A_{i}>A_{k}$ 
Penyimpangan dari konsistensi dinyatakan dengan indeks konsistensi, dengan persamaan :

$\mathrm{CI}=\frac{\lambda_{\mathrm{maks}}-\mathrm{n}}{n-1}(5)$

Dimana : $\lambda_{\text {maks }}$ = eigenvalue maksimum

$\mathrm{N}=$ ukuran matriks

indeks konsistensi (CI); matriks random dengan skala penilaian 9 (1 sampai dengan 9) beserta kebalikannya sebagai indeks Random (RI). Berdasarkan perhitungan Saaty Dengan menggunakan 500 sampel, jika "judgment" numerik diambil secara acak dari skala 1/9, 1/8 .. 1, $2 \ldots 9$ akan diperoleh rata-rata konsistensi untuk matriks dengan ukuran yang berbeda, sebagai berikut (lihat Tabel 2.1).

TABEL 2.1. NILAI INDEKS RANDOM

\begin{tabular}{c|c}
\hline $\begin{array}{c}\text { Ukuran } \\
\text { Matriks }\end{array}$ & $\begin{array}{c}\text { Indeks Random } \\
\text { (inkonsistensi) }\end{array}$ \\
\hline $1 / 2$ & 0.00 \\
\hline 3 & 0.58 \\
\hline 4 & 0.90 \\
\hline 5 & 1.12 \\
\hline 6 & 1.24 \\
\hline 7 & 1.32 \\
\hline 8 & 1.41 \\
\hline 9 & 1.45 \\
\hline 10 & 1.49 \\
\hline & \\
\hline 11 & 1.51 \\
\hline 12 & 1.48 \\
\hline 13 & 1.56 \\
\hline 14 & 1.57 \\
\hline 15 & 1.59 \\
\hline
\end{tabular}

Perbandingan antara CI dan RI untuk suatu matriks didefinisikan sebagai Rasio Konsistensi (CR).

$$
\mathrm{CR}=\frac{\mathrm{CI}}{\mathrm{RI}}
$$

Untuk model AHP, matrik perbandingan dapat diterima jika nilai Rasio Konsistensi $\leq 0.1$. Contoh perhitungan lebih detail dapat dilihat pada buku Saaty (1993).

\subsection{Technique for Order Preference by Similarity to Ideal} Solution

Metode TOPSIS (Technique for Order Preference by Similarity to Ideal Solution) sangat sederhana. Metode TOPSIS menggunakan prinsip bahwa alternatif yang terpilih harus mempunyai jarak terdekat dari solusi ideal positif dan jarak terjauh dari solusi ideal negatif dari sudut pandang geometris dengan menggunakan jarak Euclidean untuk menentukan kedekatan relatif dari suatu alternatif dengan solusi optimal.

Solusi ideal positif didefinisikan sebagai jumlah dari seluruh nilai terbaik yang dapat dicapai untuk setiap atribut, sedangkan solusi negatif ideal terdiri dari seluruh nilai terburuk yang dicapai untuk setiap atribut. Dalam penggunaan Metode TOPSIS perlu mempertimbangkan keduanya, jarak terhadap solusi ideal positif dan jarak terhadap solusi ideal negatif dengan mengambil kedekatan relatif terhadap solusi ideal positif. Berdasarkan perbandingan terhadap jarak relatifnya, susunan prioritas alternatifnya bisa dicapai. Langkah perhitungan TOPSIS :

Decision matrix D mengacu terhadap m yaitu alternatif yang akan dievaluasi berdasarkan $\mathrm{n}$ kriteria yang didefinisikan sebagai berikut :

$\mathrm{D}=\left[\begin{array}{llll}x_{11} & x_{12} & \ldots & x_{1 n} \\ x_{21} & x_{22} & \ldots & x_{2 n} \\ & & & \\ x_{m 1} & x_{m 2} & \ldots & x_{m n}\end{array}\right]$

Dengan $\mathrm{x}_{\mathrm{ij}}$ menyatakan performansi dari perhitungan untuk alternatif ke-i terhadap atribut ke-j. Langkah - langkah metode TOPSIS sebagai berikut :

1. Membangun normalized decision matrix

Elemen rij hasil dari normalisasi decision matrix $\mathrm{R}$ dengan metode Euclidean length of a vector adalah

$$
\mathrm{rij}=\frac{x i j}{\sqrt{\sum_{i=1}^{m} x^{2} i j}} \ldots \ldots \ldots \ldots
$$

2. Membangun weight normalized decision matrix.

Dengan bobot $\mathrm{W}=\left(\mathrm{w}_{1}, \mathrm{w}_{2}, \ldots . . \mathrm{w}_{\mathrm{n}}\right)$, maka normalisasi bobot matriks $\mathrm{V}$ adalah

$$
\mathrm{v}=\left[\begin{array}{cccc}
w_{1} r_{11} & w_{2} r_{12} & \ldots & w_{n} r_{1 n} \\
w_{1} r_{21} & & & \\
\cdot & & & \\
w_{1} r_{m 1} & w_{2} r_{m 2} & \ldots & w_{n} r_{m n}
\end{array}\right]
$$

3. Menentukan solusi ideal positif dan solusi ideal negatif

Solusi ideal positif dinotasikan dengan $\mathrm{A}^{+}$solusi ideal positif mencari nilai max dari kriteria setiap alternatif, sedangkan solusi ideal negatif dinotasikan dengan $\mathrm{A}^{-}$dimana solusi ideal negatif mencari nilai min dari kriteria setiap alternatif :

$A^{+}=\left\{\left(\max v_{i j} \mid j \in J\right),\left(\min v i j \mid j \in J^{\prime}\right), i=1,2,3, \ldots\right.$, $\mathrm{m}\}$

$$
=\left\{\mathrm{v}_{1}{ }^{+}, \mathrm{v}_{2}{ }^{+}, \ldots \mathrm{v}_{\mathrm{n}}{ }^{+}\right\}
$$

A- $=\left\{\left(\min v_{i j} \mid j \in J\right),\left(\max v i j \mid j \in J^{\prime}\right), i=1,2,3, \ldots\right.$, $\mathrm{m}\}$

$=\left\{\mathrm{v}_{1}{ }^{-}, \mathrm{v}_{2}^{-}, \ldots \mathrm{v}_{\mathrm{n}}^{-}\right\}$

Keterangan :

$\mathrm{J}=\{\mathrm{j}=1,2,3, \ldots \mathrm{n}$ dan $\mathrm{j}$ merupakan benefit criteria $\}$ 
$\mathrm{J}^{\prime}=\{\mathrm{j}=1,2,3, \ldots . \mathrm{n}$ dan $\mathrm{j}$ merupakan cost criteria $\}$

4. Menghitung separasi

$\mathrm{Si}^{*}$ adalah jarak (dalam pandangan Euclidean) altenatif dari solusi ideal positif didefinisikan sebagai :

$$
\mathrm{Si}^{*}=\sqrt{\sum_{j=1}^{n}\left(v_{i j}-v_{j}^{*}\right)^{2}}, \text { dengani }=1,2,3, \ldots, m
$$

Dan jarak terhadap solusi ideal negatif didefinisikan sebagai :

$$
\mathrm{S}_{\mathrm{i}}^{-}=\sqrt{\sum_{j=1}^{n}\left(v_{i j}-v_{j}{ }^{-}\right)^{2}}, \text { dengani }=1,2,3, \ldots, m
$$

5. Menghitung kedekatan relatif terhadap solusi ideal positif :

$$
\begin{aligned}
& \mathrm{C}_{\mathrm{ij}} *-\frac{S_{i}^{-}}{S_{i}^{*}+S_{i}^{-}} \text {, dengan } 0<\mathrm{C}_{\mathrm{i}} *<1 \text { dan } \mathrm{i}=1,2,3, \ldots . \\
& \text { m......(12) }
\end{aligned}
$$

6. Merangking alternatif

Setelah didapat nilai kedekatan terhadap solusi ideal langkah terakhir melakukan rangking terhadpa alternatif. Alternatif dapat dirangking berdasarkan urutan $\mathrm{C}_{\mathrm{i}}{ }^{*}$. Maka dari itu, alternatif terbaik adalah salah satu yang berjarak terpendek terhadap solusi ideal positif dan berjarak terjauh dengan solusi ideal negatif.

\section{METODE DAN DESAIN SISTEM}

\subsection{Skema Sistem Perangkingan}

Sistem akan dibuat dengan menggunakan kedua metode hbrid yaitu AHP dan TOPSIS untuk merangking seberapa besar penjualan pupuk bersubsidi per kabupaten dari beberapa kriteria yang dimasukkan oleh pengguna berdasarkan data informasi kriteria yang didapat dari pengumpulan data tiap bulan. Hal ini dapat terlihat pada Gambar 3.1 sebagai berikut.

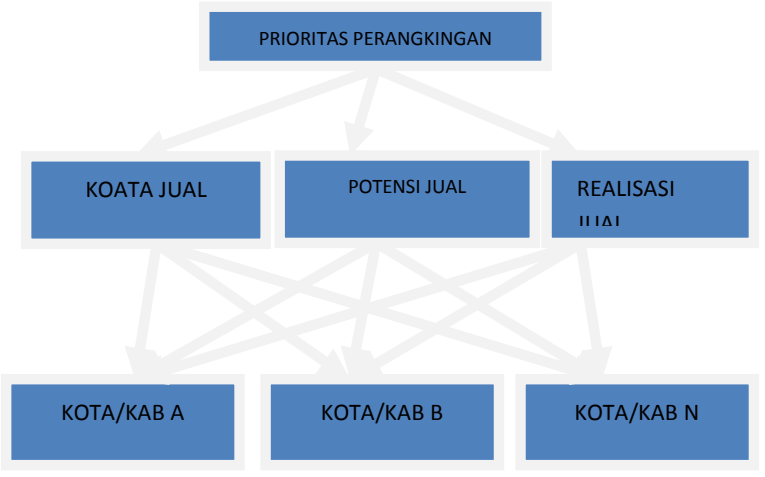

Gambar 3.1 Hierarch Topsis Ranking

\subsection{Proses Perangkingan}

Setelah mendefinisikan masalah dan menentukan solusi maka pada perancangan sistem alur sistem perangkingan distributor pupuk bersubsidi dengan menggunakan metode analytical hierarchy process dan TOPSIS digambarkan sebagai berikut lihat Gambar 3.2.

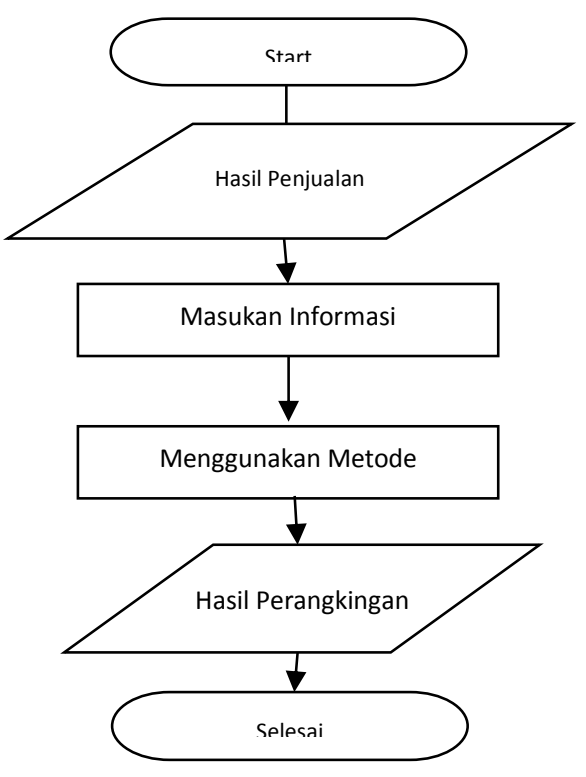

Gambar 3.2 Flowchart Desain Sistem

\subsection{Representasi Data}

3.3.1 Menentukan bobot AHP

1. Menentukan Bobot

TABEL 3.1 PERBANDINGAN BERPASANGAN

\begin{tabular}{l|c|c|c}
\hline & Plan & Distribusi & Potensi \\
\hline Plan & 1 & 0.5 & 5 \\
\hline Distribusi & 2 & 1 & 7 \\
\hline Potensi & 0.2 & 0.1429 & 1 \\
\hline Jumlah & 3.2 & 1.6429 & 13 \\
\hline
\end{tabular}

Data pembobotan di atas berdasarkan ketentuan penetapan perusahan terhadap kriteria Rencana Penjualan, Realisasi Salur dan Potensi Penjualan rumus merujuk Persamaan 1.

\section{Menghitung Matrik Kriteria}

TABEL 3.2. MATRIK KRITERIA

\begin{tabular}{c|c|c|c|c|c}
\hline & Plan & Distribusi & Potensi & Jumlah & Prioritas \\
\hline Plan & 0.3125 & 0.3043 & 0.3846 & $\mathbf{1 . 0 0 1 5}$ & $\mathbf{0 . 3 3 3 8}$ \\
\hline Distribusi & 0.6250 & 0.6087 & 0.5385 & $\mathbf{1 . 7 7 2 2}$ & $\mathbf{0 . 5 9 0 7}$ \\
\hline Potensi & 0.0625 & 0.0870 & 0.0769 & $\mathbf{0 . 2 2 6 4}$ & $\mathbf{0 . 0 7 5 5}$ \\
\hline Jumlah & $\mathbf{1}$ & $\mathbf{1}$ & $\mathbf{1}$ & $\mathbf{3}$ & $\mathbf{1}$ \\
\hline
\end{tabular}

Matrik criteria ini didapat dari pembagian masingmasing kriteria dibanding total hasil pembobotan pada Tabel 
3.1 rumus merujuk persamaan 2 dan diubah dengan merujuk rumus persamaan 3 .

3. Menghitung Matrik Penjumlahan Setiap Baris

TABEL 3.3. MATRIK PENJUMLAHAN BARIS

\begin{tabular}{c|c|c|c|c}
\hline & rencana & penyaluran & Potensi & jumlah \\
\hline Plan & 1.0015 & 0.8861 & 1.1319 & $\mathbf{3 . 0 1 9 4}$ \\
\hline Distribusi & 2.0029 & 1.7722 & 1.5847 & $\mathbf{5 . 3 5 9 7}$ \\
\hline Potensi & 0.2003 & 0.2532 & 0.2264 & $\mathbf{0 . 6 7 9 8}$ \\
\hline Jumlah & $\mathbf{3 . 2 0 4 7}$ & $\mathbf{2 . 9 1 1 4}$ & $\mathbf{2 . 9 4 2 9}$ & $\mathbf{9 . 0 5 9 0}$ \\
\hline
\end{tabular}

Matrik penjumlahan setiap baris diperoleh dari pembagian masing-masing kriteria (rencana, penyaluran dan potensi) di Tabel 3.2 dengan merjuk rumus Persamaan 4.

c. Rasio Konsistensi pada kolom jumlah Tabel 3.3 menggunakan tiga kriteria, sehingga CR pada Tabel 2.1 menggunakan matrik tiga dengan nilai 0,58 dan perhitungan rumus CR merujuk persamaan 5.

$\mathrm{n} \quad=$ banyaknya elemen

$\lambda$ maks = jumlah pada penjumlahan matriks tiap baris

n

$$
\begin{aligned}
& =\frac{9,0590}{3} \\
& =3,02
\end{aligned}
$$

CI = Consistency Index

CI $=\frac{\lambda \text { maks }-\mathrm{n}}{\mathrm{n}-1}$

$$
=\frac{3,02-3}{3-1}=0,01
$$

$\mathrm{CR}=$ Consistency Ratio

RI = Index Random Consistency

$$
\mathrm{CR}=\frac{\mathrm{CI}}{\mathrm{RI}}
$$

$\mathrm{CR} \quad=\frac{0,01}{0,58}=0,02<=0,1$ maka ratio konsistensi terpenuhi

\subsubsection{Menghitung Rangkingan TOPSIS}

TABEL 3.4. PENJUALAN PUPUK AREA

\begin{tabular}{c|l|c|c|c}
\hline \multirow{2}{*}{ No } & \multirow{2}{*}{ Kabupaten } & \multicolumn{3}{|c}{$\begin{array}{c}\text { Penjualan pupuk urea } \\
\text { bulan Januari }\end{array}$} \\
\cline { 3 - 5 } & & Renc & Salur & Potensi \\
\hline 1 & Magetan & 60,000 & 54,953 & 56,402 \\
\hline 2 & Madiun & 55,000 & 47,145 & 59,782 \\
\hline 3 & Nganjuk & 67,900 & 65,437 & 72,415 \\
\hline 4 & Bondowoso & 27,400 & 24,160 & 34,119 \\
\hline
\end{tabular}

Data pada Tabel 3.4 berdasarkan data realisasi penjualan pupuk bersubsidi PT Petrokimia Gresik tahun 2019.

1. Memasukan Bobot AHP kerumus TOPSIS

\begin{tabular}{c|l|r}
\multicolumn{3}{c}{ TABEL 3.5. BOBOT AHP HITUNG DALAM TOPSIS } \\
\hline No & \multicolumn{1}{|c|}{ Prioritas } & \multicolumn{1}{c}{ Bobot } \\
\hline 1 & rencana & 0.3338 \\
\hline 2 & penyaluran & 0.5907 \\
\hline 3 & potensi & 0.0755 \\
\hline
\end{tabular}

Data pembobotan dari Tabel 3.5 diperoleh dari nilai prioritas Tabel 3.2, nilai bobot ini akan dijadikan perhitungan

\begin{tabular}{|c|c|c|c|}
\hline Kabupaten & Renc & Salur & Potensi \\
\hline Magetan & 0.5480 & 0.5466 & 0.4916 \\
\hline Madiun & 0.5024 & 0.4689 & 0.5211 \\
\hline Nganjuk & 0.6202 & 0.6509 & 0.6312 \\
\hline Bondowoso & 0.2503 & 0.2403 & 0.2974 \\
\hline
\end{tabular}
perangkingan dalam TOPSIS.

2. Normalisasi Matrik

TABEL 3.6. NORMALISASI MATRIK

Pada Tabel 3.6 data dihasilkan dari pembagian masingmasing kabupaten dan kriteria (Renc, Real dan Potensi) dengan total penjualan per Kabupaten dengan merujuk Persamaan 6.

3. Pembobotan pada matriks yang telah dinormalisasikan

\begin{tabular}{l|c|c|c}
\multicolumn{4}{c}{ TABEL 3.7. MATRIK NORMALISASI TERBOBOT } \\
\hline Kabupaten & Renc & Salur & Potensi \\
\hline Magetan & 0.1829 & 0.3229 & 0.0371 \\
\hline Madiun & 0.1677 & 0.2770 & 0.0393 \\
\hline Nganjuk & 0.2070 & 0.3845 & 0.0476 \\
\hline Bondowoso & 0.0836 & 0.1419 & 0.0224 \\
\hline
\end{tabular}

Matrik keputusan normalisasi terbobot diperoleh dari pengalian di tiap kolom Tabel 3.6 dengan masing-masing row Tabel 3.5 merujuk pada persamaan 7 .

4. Menghitung solusi ideal positif dan solusi ideal negative

\begin{tabular}{c|c|c}
\multicolumn{3}{|c}{ TABEL 3.8. SOLUSI IDEAL POSITIF DAN NEGATIF } \\
\hline positif & v1 & 0.2070 \\
\hline & v2 & 0.3845 \\
\hline & v3 & 0.0476 \\
\hline negatif & v1 & 0.0836 \\
\hline & v2 & 0.1419 \\
\hline & v3 & 0.0224 \\
\hline
\end{tabular}


Solusi Ideal Positif dan Negatif adalah mencari nilai 'Max' dan 'Min' pada Tabel 3.7 (v1=renc, v2=real, v3=pot) merujuk persamaan 8 untuk positif dan persamaan 9 untuk negative.

\section{Menghitung Separation Measure}

TABEL 3.9. SEPARATION MEASURE

\begin{tabular}{c|c|c}
\hline positif & s1 & 0.0670 \\
\hline & $\mathrm{s} 2$ & 0.1148 \\
\hline & $\mathrm{s} 3$ & 0.0000 \\
\hline & $\mathrm{s} 4$ & 0.2733 \\
\hline negatif & $\mathrm{s} 1$ & 0.2070 \\
\hline & $\mathrm{s} 2$ & 0.1600 \\
\hline & $\mathrm{s} 3$ & 0.2733 \\
\hline & $\mathrm{s} 4$ & 0.0000
\end{tabular}

Menghitung Separasi Positif menggunakan perhitungan penjumlahan antara kolom Magetan (Tabel 3.7) dengan Row Positif (Tabel 3.8) dengan merujuk rumus persamaan 10 Dan jarak terhadap solusi ideal didefinisikan dengan persamaan 11 .

6. Menghitung kedekatan relatif dengan solusi ideal

TABEL 3.10. HASIL SOLUSI IDEAL

\begin{tabular}{|l|c|c|}
\hline Magetan & v1 & 0.2445 \\
\hline Madiun & v2 & 0.4177 \\
\hline Nganjuk & v3 & 0.0000 \\
\hline Bondowoso & V4 & 1.0000 \\
\hline
\end{tabular}

Yang

terpilih

Kedekatan relatif solusi ideal diperoleh dari pembagian rata-rata antara nilai positif dan negatif pada Tabel 3.9 dengan merujuk pada Persamaan 12. Dari hasil perhitungan solusi Ideal Negatif yang diperoleh dari persamaan 12, diperoleh data terkecil adalah kabupaten Nganjuk yaitu dengan nilai 0,0000, sedangkan untuk kabupaten yang memperoleh data tertinggi adalah Kabupaten Madiun dengan nilai 0,4177.

\section{HASIL DAN PEMBAHASAN}

Dengan panduan data tahun 2019 pada kabupaten di seluruh Indonesia dilakukan pengujian sistem dengan langkah proses yang terjadi pada sistem pendukung keputusan perangkingan penjualan pupuk bersubsidi per kabupaten dengan metode AHP dan TOPSIS :

TABEL 4.1. HASIL PERANGKINGAN KONV DAN SYSTEM

\begin{tabular}{c|l|l|l|l|l|l}
\hline \multirow{2}{*}{$\begin{array}{c}\text { N } \\
\text { o }\end{array}$} & Kabupaten & \multicolumn{3}{|c|}{ Penjualan } & \multicolumn{2}{c}{ Komulatif } \\
\cline { 3 - 7 } & $\begin{array}{l}\text { Renca } \\
\text { na }\end{array}$ & $\begin{array}{l}\text { Realis } \\
\text { asi }\end{array}$ & $\%$ & Sistem & Manual \\
\hline 1 & Lumajang & 1.216 & 300 & 25 & 0,499318 & 0,499318 \\
\hline 2 & Surabaya & 10 & - & - & 0,499339 & 0,499339 \\
\hline 3 & $\begin{array}{l}\text { Kota } \\
\text { Pasuruan }\end{array}$ & 20 & 8 & 40 & 0,499340 & 0,499340 \\
\hline
\end{tabular}

\begin{tabular}{c|l|l|l|l|l|l}
\hline 4 & $\begin{array}{l}\text { Kota } \\
\text { Probolinggo }\end{array}$ & 60 & 25 & 42 & 0,499341 & 0,499341 \\
\hline 5 & Kota Malang & 100 & 50 & 50 & 0,499344 & 0,499344 \\
\hline 6 & Kota Blitar & 250 & 105 & 42 & 0,499347 & 0,499347 \\
\hline 7 & Bangkalan & 40 & 20 & 50 & 0,499354 & 0,499354 \\
\hline 8 & Bojonegoro & 1.380 & 1.040 & 75 & 0,499368 & 0,499368 \\
\hline 9 & Tuban & 810 & 800 & 99 & 0,499385 & 0,499385 \\
\hline 10 & Lamongan & 2.260 & 1.400 & 62 & 0,499398 & 0,499398 \\
\hline 11 & Sidoarjo & 900 & 658 & 76 & 0,499428 & 0,499428 \\
\hline 12 & Pasuruan & 1.100 & 622 & 57 & 0,499462 & 0,499462 \\
\hline 13 & Gresik & 860 & 825 & 96 & 0,499502 & 0,499502 \\
\hline 14 & Banyuwangi & 1.600 & 1.370 & 86 & 0,499541 & 0,499541 \\
\hline 15 & Kota Batu & 2.200 & 1.700 & 77 & 0,499623 & 0,499623 \\
\hline 16 & Malang & 5.000 & 3.263 & 65 & 0,499686 & 0,499686 \\
\hline
\end{tabular}

Dari pengujian sistem pada Tabel 4.1 dihasilkan perangkingan pupuk bersubsidi per kabupaten di Propinsi Jawa Timur dengan peringkat terendah adalah Lumajang dengan total nilai paling rendah yaitu 0,499318, maka kabupaten Lumajang akan dilakukan tindak lanjut paling utama dan kabupaten lain yang ada dalam table hasil juga bakal dilakukan tindak lanjut evaluasi karena perbandingan rencana, realisasi dan potensi yang masih kurang dari $100 \%$ dengan penjualan 300 ton dari target rencana penjualan 1.216 ton.

\section{PENUTUP}

\section{$5.1 \quad$ Kesimpulan}

Simpulan dari hasil penelitian yang dilakukan adalah diperoleh hasil penjualan terendah adalah Lumajang dengan nilai 0,4993 karena penjualan masih kurang dari $100 \%$ yaitu 300 ton dari total rencana 1216 ton, dengan mengetahui penjualan yang kurang dari $100 \%$ di masing-masing kabupaten propinsi Jawa Timur maka distribusi pupuk subsidi dapat dilakukan secara cepat.

\subsection{Saran}

1. Aplikasi tersebut perlu di kembangkan sistem yang lebih otomatis

2. Sistem dikembangkan berbasis android

3. Diperlukan uji coba dengan gabungan metode lainnya.

\section{UCAPAN TERIMA KASIH}

Ucapan terima kasih saya sampaikan pada teman-teman dosen atas saran dan masukannya, serta keluarga telah mendukung dan memberikan masukan demi kesempurnaan makalah ini sehingga makalah ini menjadi berkualitas dan dapat dipublikasikan.

\section{DAFTAR PUSTAKA}

[1] Ghosh, Dipendra Nath. 2011. Analytic Hierarchy Process \& TOPSIS Method to Evaluate Faculty Performance in Engineering Education. UNIASCIT. Vol 1 (2): 63-70.

[2] Juliyanti, Mohammad Isa Irawan, \& Imam Mukhlash. 2011 Pemilihan Guru Berprestasi Menggunakan Metode AHP dan TOPSIS Prosiding Seminar Nasional Penelitian, Pendidikan dan Penerapan MIPA. Universitas Negeri Yogyakarta. 
[3] Kadarsah Suryadi, Ir. M. Ali Ramdani, MT. Sistem Pendukung Keputusan. 1998, Suatu Wacana Struktural Idealisasi dan Implementasi Konsep Pengambilan Keputusan. Bandung

[4] Khosravi, J., Mohammad A.A., Mohammad R.A., \& Mir Hosein Peyman. 2011. Application of Multiple Criteria Decision Making System Compensatory (TOPSIS) in Selecting of Rice Milling System. World Applied Iran Sciences Journal. Vol.13 (11) pp:2306-2311

[5] Maharrani, Ratih Hafsarah, Abdul Syukur, Tyas Catur P. 2010. Penerapan Metode Analytical Hierarchi Process Dalam Penerimaan Karyawan Pada PT. Pasir Besi Indonesia. Jurnal Teknologi Informasi.Vol.6 No.1

[6] Saaty, T.L.2008. Decision Making with Analytic Hierarch Process.International Journal Services Science Vol.1 No 1

[7] Turban, E. Sharda, R. Dele, D. 2011. Decision Support and Business Intelligence Systems. New Jersey : Pearson Education Inc.

[8] Yoon, K.P. and Hwang, C.L. 1995. Multiple Attribute Decision Making: An Introduction, Sage Publications, Thousand Oaks, CA.

[9] Nooramin, Amir Saeed, Jafar Sayareh, Mansoor Kiani Moghadam, HAmed Rezaee Alizmini. 2012. TOPSIS and AHP techniques for selecting the most efficient marine container yard gantry crane. Operational Research Society of India (Apr-Jun 2012) 49(2):116-132

[10] Sinaga, Johannes. 2009, Penerapan Analytical Hierarchy Process (AHP) Dalam Pemilihan Perusahaan Badan Usaha Milik Negara (BUMN) Sebagai Tempat Kerja Mahasiswa Universitas Sumatera Utara.

[11] Saaty, T.L. 2000. The Fundamentals of Decision Making and Priority Theory with the Analytic Hierarchy Process. Pittsburgh: RWS Publication University of Pittsburgh.

[12] Yoenanto, Nono Herry. 2010. Hubungan antara Selfregulated Learning dengan Selfefficacy pada Siswa Akselerasi Sekolah Menengah Pertama di Jawa Timur. Jurnal Insan Media Psikologi. Vol 12 No 2 Tahun 2 
JURNAL TEKNOLOGI PROSES DAN INOVASI INDUSTRI, VOL. 4, NO. 1, JULI 2019

HALAMAN INI DIKOSONGKAN 